\title{
Use of mitochondrial cytochrome $b$ sequences to determine the origin of captive Asian tapirs Tapirus indicus: implications for conservation
}

\author{
Yuttamol Muangkram ${ }^{1,2}$, Worawidh Wajjwalku ${ }^{2, *}$, Chaleow Salakij' ${ }^{2}$, \\ Nongnid Kaolim ${ }^{2}$, Boripat Siriaroonrut ${ }^{3}$, Sumate Kamolnorranath ${ }^{3}$, Wanlaya Tipkantha ${ }^{3}$, \\ Umaporn Maikaew ${ }^{4}$, Warisara Thomas ${ }^{5}$, Kanda Polsrila ${ }^{6}$, Kwanreaun Dong sa-ard ${ }^{7}$, \\ Saowaphang Sananu ${ }^{8}$, Anuwat Wattananorrasate ${ }^{9}$ \\ ${ }^{1}$ The Graduate School, Kasetsart University, Chatuchak, Bangkok 10900, Thailand \\ ${ }^{2}$ Department of Pathology, Faculty of Veterinary Medicine, Kasetsart University, Kamphaengsaen, Nakhon Pathom 73140, Thailand \\ ${ }^{3}$ Endangered Species Conservation and Research Institute, Zoological Park Organization, Dusit, Bangkok 10300, Thailand \\ ${ }^{4}$ Khao Kheow Open Zoo, Sriracha, Chonburi 20110, Thailand \\ ${ }^{5}$ Nakhon Ratchasima Zoo, Muang, Nakhon Ratchasima 30000, Thailand \\ ${ }^{6}$ Song Khla Zoo, Muang, Song Khla 90000, Thailand \\ ${ }^{7}$ Chiang Mai Zoo, Muang, Chiang Mai 50000, Thailand \\ ${ }^{8}$ Dusit Zoo, Dusit, Bangkok 10300, Thailand \\ ${ }^{9}$ Safari World Public Company Limited, Klongsamwa, Bangkok 10510, Thailand
}

\begin{abstract}
Populations of the Endangered Asian tapir Tapirus indicus in Thailand have been severely fragmented and isolated and may be facing a high risk of extinction. Their genetic diversity and population viability remains unknown. The main aim of this study was to assess the genetic diversity of the Asian tapir using the complete mitochondrial cytochrome $b$ gene (1140 bp). We collected 31 blood samples from captive individuals. Two polymorphic sites were found, contributing to 3 maternal lineages: Ti-1 $(n=15)$, Ti-2 $(n=11)$, and Ti-3 $(n=5)$. Comparative analysis with GenBank sequences of other Asian tapirs found another 17 variable sites. These results suggest that there may be up to 7 distinct haplotypes of $T$. indicus. Furthermore, the pattern of the haplotype distribution corresponded to natural geographic boundaries, including the Isthmus of Kra and the Malacca Strait. One unique haplotype found in Sumatra was genetically distinct from 3 haplotypes found in Thailand and 3 haplotypes from Malaysia. One haplotype shared between Thai and Malaysian populations indicated a possible origin in the tropical rainforest along the Thai-Malay border. In general, the diverged geographic distribution of these haplotypes illustrates the phylogeographic history of the family Tapiridae (T. indicus, $T$. terrestris, $T$. pinchaque, and $T$. bairdii) based on our 963 bp cytochrome $b$ sequences. These baseline genetic data have the potential to enhance effective management of tapirs held in captive breeding programs. However, there is still an urgent need to identify and maintain the genetic diversity of these distinct populations in the wild.
\end{abstract}

KEY WORDS: Cytochrome $b$ gene $\cdot$ Genetic diversity · Malayan tapir · Phylogenetic analysis · Thailand Resale or republication not permitted without written consent of the publisher

\section{INTRODUCTION}

In Thailand, the Asian tapir Tapirus indicus (Desmarest 1819) has been categorized as a 'reserved' species by the Wildlife Preservation and Protection
Act B.E. 2535, meaning that this species may not be illegally hunted, bred, possessed, traded, exported, or imported. It is also categorized as Endangered on the 2008 IUCN Red List of Threatened Species (www.iucnredlist.org) (Lynam et al. 2008) and on Appendix I of 
CITES. The geographic distribution of the Asian tapir is distinct from the other 3 extant species, which are found in Neotropical America, viz. lowland tapir $T$. terrestris, mountain tapir T. pinchaque, and Baird's tapir T. bairdii (Carter 1984). The pattern of genetic distribution of tapirs appears to correspond closely to their demographic history. Representatives of the family Tapiridae have been identified from Oligocene fossils found in North America and Europe (Schoch 1989). Neotropical tapirs diverged from the Asian tapir approximately 20 to 30 million years ago (Ashley et al. 1996, Norman \& Ashley 2000, Pitra \& Veits 2000) during the late Miocene (Padilla \& Dowler 1994, Hulbert 1995). The earliest ancestor of the South American tapirs was recorded in the early Pleistocene in Argentina (Tonni 1992). The distribution of the newly derived clade of American tapirs is thought to be influenced by the presence of the Isthmus of Panama, and to have split from the ancestral clade approximately 3 million years ago (Ashley et al. 1996).

The current range of the Asian tapir is limited to the tropical rainforests of Southeast Asia, including Thailand, Myanmar, Malaysia, and the island of Sumatra in Indonesia (Woodruff 2003). Regionally, the species is sensitive to changes in forest cover, and the distribution of forest cover has been severely fragmented in parts of the tapir's range, leading to small populations (10 to 15 individuals) remaining in disjunct habitat (Lynam et al. 2008). In Thailand, tapir populations may be more stable, as rates of forest loss have decreased significantly in recent years (Lynam et al. 2012). Genetic monitoring has long been recognized as an important tool to protect endangered species from extinction (O'Brien 1994), and integrating genetic data with ecological data has been increasingly applied to conservation to assess the status of threatened and endangered species. The genetic management of ex situ populations is also critical to the persistence of small populations in captivity (Frankham 1995, Slate et al. 2000, Frankham et al. 2002, Keller \& Waller 2002).

Previous genetic studies of the family Tapiridae have examined mitochondrial genes such as cytochrome $C$ oxidase subunit I, cytochrome $C$ oxidase subunit II (Ashley et al. 1996), 12S rRNA (Springer 1997, Norman \& Ashley 2000, Murphy et al. 2001), 16S rRNA (Murphy et al. 2001, O'Leary \& Gatesy 2008), and cytochrome $b$ (Pitra \& Veits 2000, Arnason et al. 2008, Rovie-Ryan et al. 2008, Ogata et al. 2009, De Thoisy et al. 2010, Sanches et al. 2011, Steiner \& Ryder 2011). Each coding gene has provided a different degree of phylogenetic resolution at the taxonomic level. Moreover, the mitochondrial cytochrome $b$ gene has been reliably used for assessing genetic variation in mammals due to its moderate evolutionary rate. Previous studies of Asian tapirs have shown 6 haplotypes with 17 variable sites $(n=29)$ using available cytochrome $b$ sequences compiled from GenBank (Pitra \& Veits 2000, Rovie-Ryan et al. 2008, Ogata et al. 2009, Steiner \& Ryder 2011). The distribution of each haplotype shows that the intra-species relationship is largely influenced by the Isthmus of Kra and the Malacca Strait. These 2 natural biogeographic disjunctions have been shown to act as barriers for other Southeast Asian species, including mammals, birds, frogs, and snakes (Hughes et al. 2003, Meijaard 2003, De Bruyn et al. 2005, Inger \& Voris 2008, Liao et al. 2009).

In total, 243 polymorphic sites are recognized across all 4 extant species of tapir (Pitra \& Veits 2000, Arnason et al. 2008, De Thoisy et al. 2010, Sanches et al. 2011, Steiner \& Ryder 2011). De Thoisy et al. (2010) showed a phylogeographic relationship between lowland and mountain tapirs within South America, and a relationship between Baird's tapir and another extant American tapir was described by Steiner \& Ryder (2011). However, little work has been done to describe the phylogenetic relationships of the Asian species.

The primary goal of this study was to investigate the genetic diversity of captive Asian tapirs in Thailand and to compare our sequences with available data from GenBank to provide baseline genetic information for this species, and a putative geographic origin for captive specimens. We also analyzed the comparative phylogenetic relationships within the family Tapiridae. The results from this study provide valuable data for the conservation management of both ex situ and in situ populations of the 4 extant species of this family.

\section{MATERIALS AND METHODS}

Blood samples were collected from 31 captive Asian tapirs held in 5 zoos registered under the Zoological Park Organization of Thailand (Dusit Zoo, Khao Kheow Open Zoo, Chiang Mai Zoo, Nakhon Ratchasima Zoo, and Song Khla Zoo) and 1 private zoo. For genetic analysis, DNA was extracted from each sample using the QIAamp ${ }^{\circledR}$ blood and tissue kit (Qiagen) according to the manufacturer's instructions. The complete mitochondrial cytochrome $b$ gene was amplified using the forward primer on tRNA $^{\text {Glu }}$ (5'-CAT GAC TAA TGA TAT GAA AAA CC- $\left.3^{\prime}\right)$ and the reverse primer on $\operatorname{tRNA}{ }^{\text {Thr }}\left(5^{\prime}-\mathrm{CTT}\right.$ 
TTC TGG TTT ACA AGA CCA-3') with DreamTaq ${ }^{\circledR}$ DNA Polymerase (Fermentas International). DNA was amplified by PCR in a reaction volume of $100 \mu \mathrm{l}$ which included $0.1 \mu \mathrm{M}$ of each primer, $200 \mu \mathrm{M}$ dNTP, $0.25 \mathrm{U}$ Taq polymerase, $1 \mu \mathrm{l}$ of $10 \times\left(\mathrm{NH}_{4}\right)_{2} \mathrm{SO}_{4}$ buffer, and $1 \mathrm{mM}$ of $\mathrm{MgCl}_{2}$. Each PCR cycle consisted of 30 cycles of denaturation for $30 \mathrm{~s}$ at $94^{\circ} \mathrm{C}$, annealing for $30 \mathrm{~s}$ at $53^{\circ} \mathrm{C}$, and extension for $45 \mathrm{~s}$ at $72^{\circ} \mathrm{C}$. The correct PCR product was first confirmed using $2 \%$ agarose gel electrophoresis and purified using a QIAquick ${ }^{\circledR}$ PCR purification kit (Qiagen). The PCR products were then sent to First BASE Laboratories Sdn Bhd in Malaysia for sequencing. The cytochrome $b$ fragments investigated in this study have been deposited in GenBank under accession numbers JX014321 to JX014351. The sequences were aligned using CLUSTAL W (Thompson et al. 1994) and combined with other Tapirus indicus sequences compiled from GenBank (Table 1). Cytochrome $b$ sequences from sister taxa were also analyzed, including $T$. terrestris, $T$. pinchaque, and T. bairdii (Table 1), as well as a representative outgroup, Rhinoceros sondaicus (accession number AJ245725; Tougard et al. 2001).

Phylogenetic relationships among the compiled cytochrome $b$ sequences were constructed using a 'find best-fit' substitution model with the best Bayesian information criterion (BIC) computed by the maximum likelihood statistical method (Saitou \& Nei 1987, Nei \& Kumar 2000) implemented in CLUSTAL W (Thompson et al. 1994) via MEGA5 (Tamura et al. 2011). The reliability of the nodes was assessed by 10000 bootstraps (Felsenstein 1985). Median-joining networks

Table 1. Tapirus spp. Tapir sequences analyzed in this study. Length 1 (L1): $1140 \mathrm{bp}$; Length 2 (L2): 975 to <1140 bp; Length 3 (L3): 321 to $344 \mathrm{bp}$

\begin{tabular}{|c|c|c|c|}
\hline GenBank accession no. & L1 & L2 L3 & Source \\
\hline \multicolumn{4}{|l|}{ Tapirus indicus } \\
\hline JX014321-JX014351 & - & & This study \\
\hline AF145734 & $\bullet$ & & Pitra \& Veits (2000) \\
\hline AB469774-AB469776 & & - & Ogata et al. (2009) \\
\hline EU224327-EU224339 & & - & Rovie-Ryan et al. (2008) \\
\hline JF718881 & - & & Steiner \& Ryder (2011) \\
\hline \multicolumn{4}{|l|}{ Tapirus bairdii } \\
\hline JF718880 & $\bullet$ & & Steiner \& Ryder (2011) \\
\hline \multicolumn{4}{|l|}{ Tapirus pinchaque } \\
\hline JF718878 & $\bullet$ & & Steiner \& Ryder (2011) \\
\hline GQ259955-GQ259957 & & - & De Thoisy et al. 2010 \\
\hline \multicolumn{4}{|l|}{ Tapirus terrestris } \\
\hline JF718879 & - & & Steiner \& Ryder (2011) \\
\hline AF056030 & $\bullet$ & & Pitra \& Veits (2000) \\
\hline AJ428947 & - & & Arnason et al. (2008) \\
\hline GQ259910-GQ259954 & - & - & De Thoisy et al. (2010) \\
\hline
\end{tabular}

between all 4 extant Tapiridae species were constructed via NETWORK 4.6.1.0 (Bandelt et al. 1999).

\section{RESULTS}

Phylogenetic analysis of the 31 tapirs based on the complete mitochondrial cytochrome $b$ gene (1140 bp) revealed 3 haplotypes: Ti-1 $(\mathrm{n}=15)$, Ti-2 $(\mathrm{n}=11)$, and Ti-3 $(n=5)$. Two singleton variable sites were found as 2 types of transitional substitution ( $\mathrm{C}$ to $\mathrm{T}$ and $\mathrm{T}$ to C). Nucleotide diversity (Pi) was 0.00117 . The most common nucleotide was adenine $(31.05 \%)$ followed by cytosine, thymine, and $12.37 \%$ for guanine. For amino acid translation, we found amino shifts influenced by transitional substitutions at position 710 of the cytochrome $b$ gene sequences that could be divided into 2 groups: (1) Ti-1 and (2) Ti-2 and Ti-3. Serine (237) of Ti-1 (TCA) shifted to leucine (237) of Ti-2 and Ti-3 (TTA).

Comparative analysis with previous studies of the Asian tapir (Pitra \& Veits 2000, Rovie-Ryan et al. 2008, Ogata et al. 2009, Steiner \& Ryder 2011) indicated 7 possible haplotypes with 17 polymorphic sites (Table 2). The substitutions included both transitions and transversions. Additional analysis of amino acid variation found 3 different sites: (1) serine 29 (TCC) $\leftrightarrow$ alanine 29 (GCA) from the study of Rovie-Ryan et al. (2008), found only in Malaysia; (2) serine 237 (TCA) $\leftrightarrow$ leucine 237 (TTA); and (3) isoleucine (ATC) $\leftrightarrow$ leucine (CTC) from the study of Ogata et al. (2009), found only on the island of Sumatra in Indonesia.

The geographic distribution of haplotypes was divided into 5 possible geographic clusters - (1) Thailand: Ti-1 and Ti-2 (Ogata et al. 2009, present study); (2) Thailand and Malaysia: Ti-3 (Ogata et al. 2009, present study); (3) Malaysia: Ti-5 and Ti-6 (RovieRyan et al. 2008); (4) the island of Sumatra, Indonesia: Ti-7 (Ogata et al. 2009); and (5) unknown origin: Ti-4 (Pitra \& Veits 2000, Steiner \& Ryder 2011; our Fig. 1).

Comparative phylogenetic relationships of the family Tapiridae based on the mitochondrial cytochrome $b$ gene showed that each species was monophyletic (Fig. 2). The BIC selected the Kimura 2-parameter model with discrete gamma distribution as having the best fit.

The relationships of the 4 extant species in the family Tapiridae were determined using NETWORK (Bandelt et al. 1999) based on 963 bp cytochrome $b$ sequences from the present study and reference sequences (Table 1) with 208 polymorphic sites. The 
Table 2. Tapirus indicus. Seventeen polymorphic sites of $T$. indicus based on the mitochondrial cytochrome $b$ gene (1140 bp) were analyzed using sequences obtained from this study and reference GenBank sequences from Table 1. The baseline for these sequences corresponds to position number 14176 of the complete mitochondrial genome of T. terrestris. Dots indicate base pairs identical to the Ti-1 haplotype of $T$. indicus. Dashes indicate no recorded nucleotide

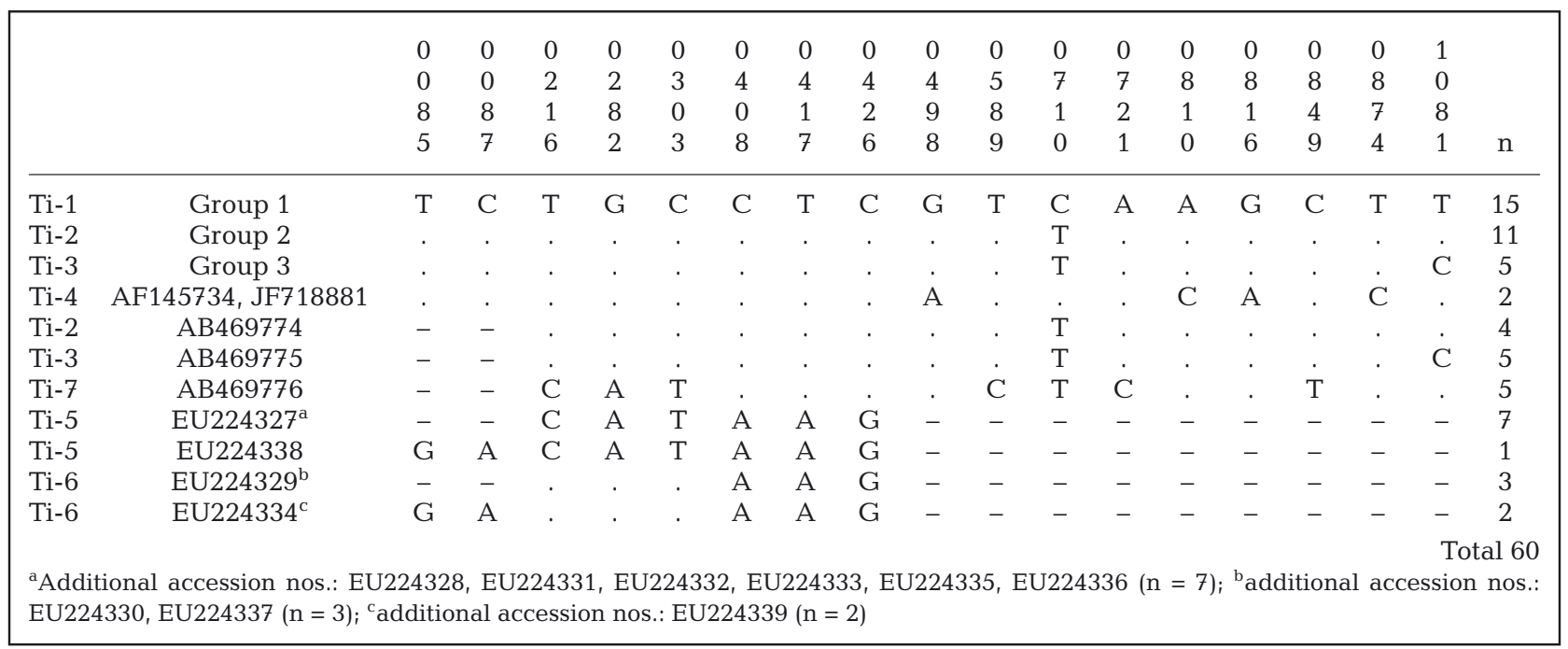

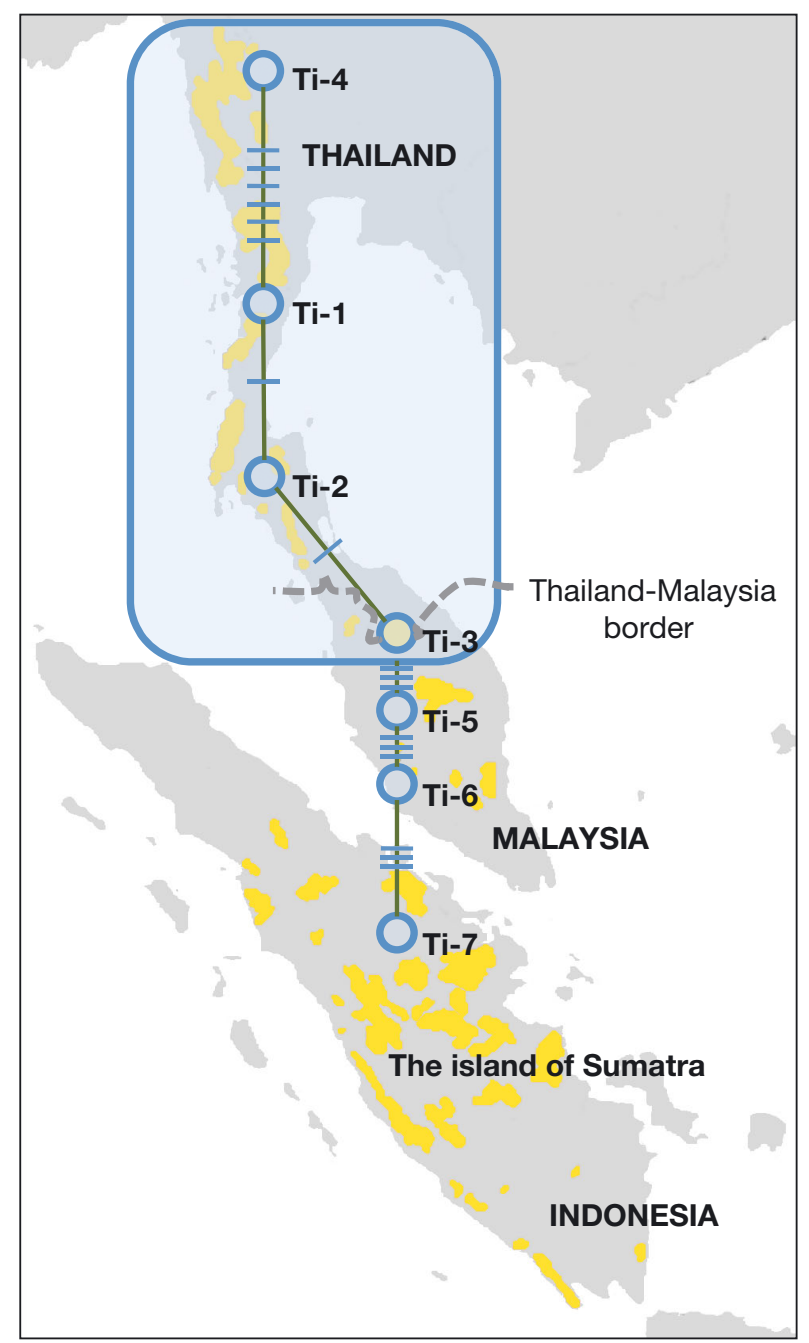

results do not include short length sequences (321 to $344 \mathrm{bp}$ ) of Ti-5 and Ti-6. The pattern of haplotype distribution is correlated with each geographic region (Fig. 3).

\section{DISCUSSION}

In total, the Asian tapir $(\mathrm{n}=60)$ showed 7 possible haplotypes based on mitochondrial cytochrome $b$ gene sequences. We identified 3 haplotypes in the captive tapir population in Thailand: Ti-1, Ti-2, and Ti-3. The majority of the captive individuals $(48.4 \%)$ were haplotype Ti-1, which was a new haplotype found only in Thailand. Ti-2 and Ti-3 were similar to those described by Ogata et al. (2009). Ti-2 was found in Thailand and Ti-3 in Thailand and Malaysia. Ti-4

Fig. 1. Tapirus indicus. Comparative phylogenetic relationship between sequences from this study and reference sequences based on partial mitochondrial cytochrome $b$ gene sequences (286 bp; position 142 to 427) of the Asian tapir. This information enabled us to distinguish haplotypes (blue circles) according to geographic region: 1 haplotype was found on the island of Sumatra, Indonesia and 2 haplotypes were found only on the Malay peninsula (Malaysia). One grouping of a large population (blue rectangle) based on longer mitochondrial cytochrome $b$ gene sequences (975 bp) with 12 sites was grouped into Ti-1 and Ti-2 (Thailand), Ti-3 (Thailand/Malaysia), and Ti-4 (unknown origin). The blue horizontal lines refer to the number of nucleotide substitutions, and the yellow area indicates the current Asian tapir distribution modified from the IUCN Red List of Threatened Species (www.iucnredlist.org) 


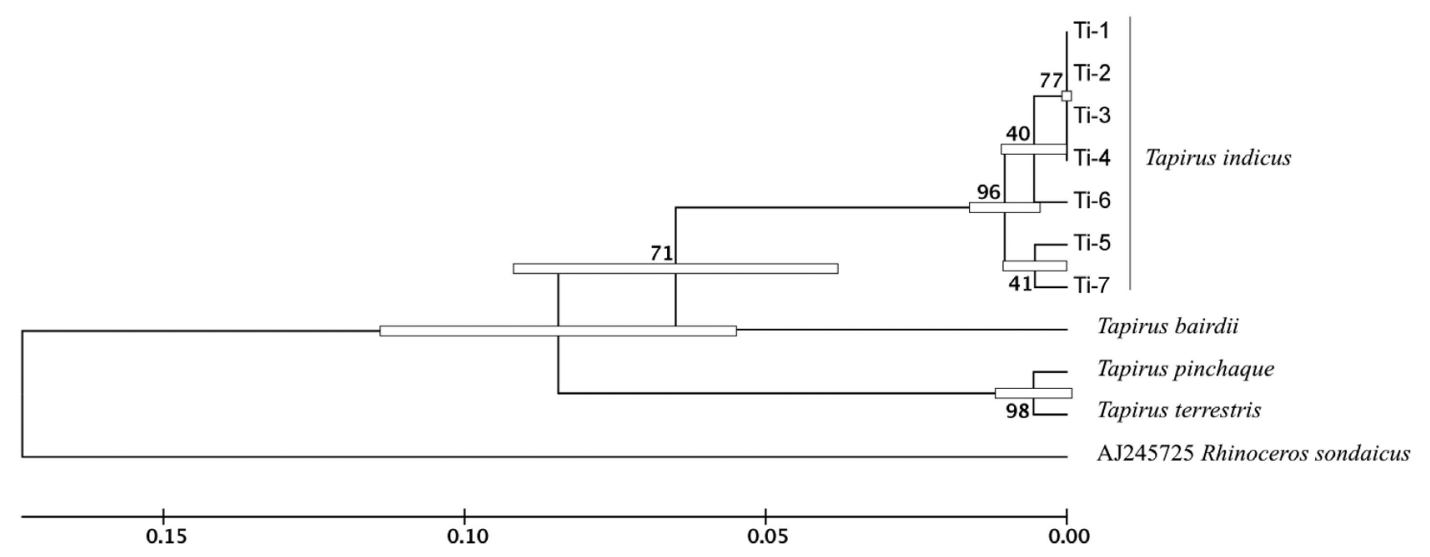

Fig. 2. Tapirus spp. Consensus maximum likelihood tree based on the mitochondrial cytochrome $b$ gene, illustrating the phylogenetic relationship of the family Tapiridae with Rhinoceros sondaicus as the outgroup. The tree was computed using a discrete gamma distribution rate categories (rate $=5$ ) Kimura 2-parameter model. Asian tapirs (Ti-1 to Ti-7) from Southeast Asia are isolated from 3 extant species of Neotropical tapirs (Table 1). Baird's tapir T. bairdii from Central America is also genetically isolated from South American tapirs. Mountain tapirs T. pinchaque have the closest relationship with lowland tapirs T. terrestris. All nodes were supported by the bootstrap values (10 000 replicates). Scale bar corresponds to nucleotide substitutions per site

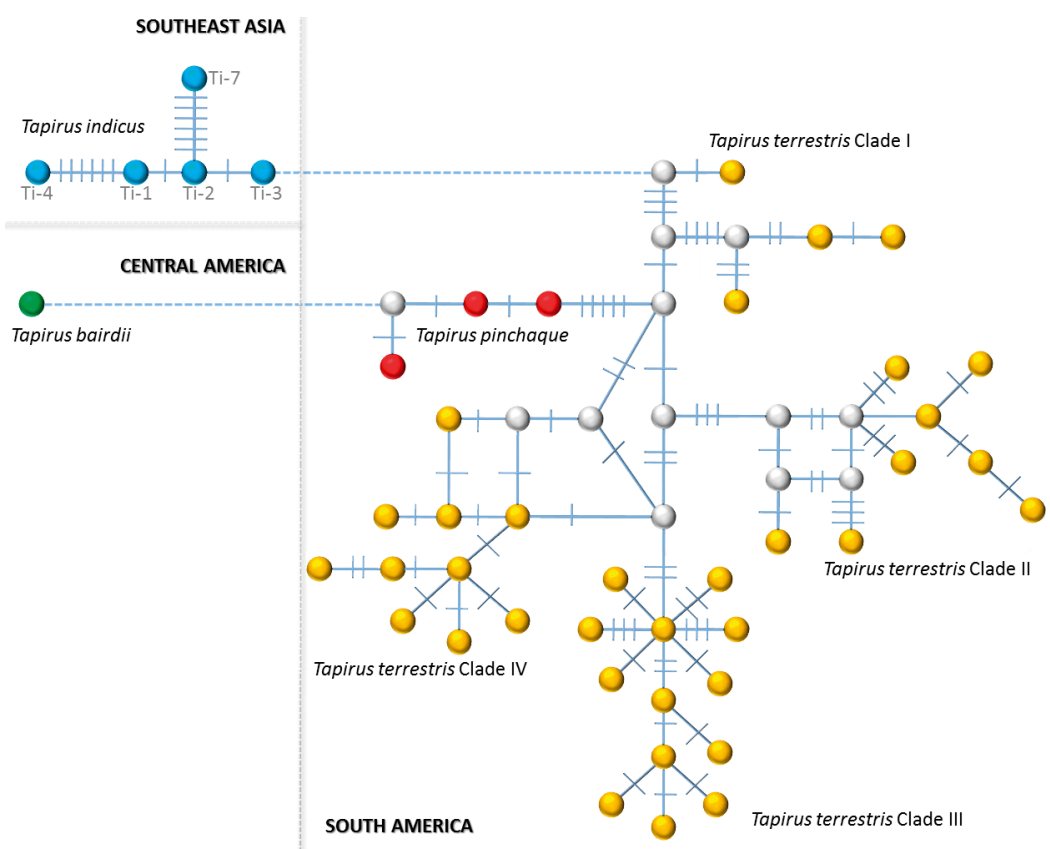

Fig. 3. Tapirus spp. Median-joining NETWORK diagram of the family Tapiridae. Colored circles refer to reference samples - blue: T. indicus from Southeast Asia; green: T. bairdii from Central America; red: T. pinchaque from South America; yellow: T. terrestris from South America. T. terrestris populations were divided into 4 clades as modified from De Thoisy et al. (2010), and the light grey circles refer to mutated positions. The short blue lines refer to the number of nucleotide substitutions. Dashed lines represent $>10$ nucleotide substitutions

had an unknown origin (Pitra \& Veits 2000, Steiner \& Ryder 2011). Ti-5 and Ti-6 were found on the Malay Peninsula (Rovie-Ryan et al. 2008). Ti-7 was located only on the island of Sumatra in Indonesia (Ogata et al. 2009). Ti-4 indicated conserved and variable sites, which were quite similar to tapirs originating from mainland Indochina. Despite 4 different nucleotides, the amino acid sequences of Ti- 4 showed $100 \%$ match with Ti-1 from Thailand. Therefore, it is highly possible that Ti-4 was obtained from Thailand. For Ti-3, we suggest that this haplotype may have been derived from the extensive Thai-Malay transboundary rainforests. Future sampling of tapir populations from Peninsular Malaysia will further elucidate the demographic history of the Asian tapir.

In addition, landscape genetic sampling of wild tapirs will provide a better understanding of factors influencing phylogeographic patterns, for example, the Isthmus of Kra, which has previously been shown to act as a biogeographic barrier for birds and mammals endemic to Southeast Asia. The Isthmus of Kra might serve as a significant biogeographic transition between the Indochinese mainland and Sundaic regions, which include the Malay Peninsula and the Malay Archipelago islands west of the Wallace Line (Corbet \& Hill 1992, Woodruff 2003).

Comparative phylogenetic analysis of the family Tapiridae with all available databases compiled from GenBank found 243 variable sites. The results showed that Southeast Asian and Central American 
tapirs were completely isolated from South American tapirs. Lowland and mountain tapirs were closely related sister taxa. Our phylogenetic results based on cytochrome $b$ revealed identical results as reported in studies of cytochrome $c$ oxidase subunit II (Ashley et al. 1996) and 12S rRNA (Norman \& Ashley 2000).

Recently, populations of wild Asian tapirs in Thailand have stabilized (Lynam et al. 2012) due to a decrease in the rate of deforestation following a ban on commercial logging in 1989, with protected areas now covering roughly $18 \%$ of land area across the country. In general, maintaining large intact areas of undisturbed rainforest is important for Asian tapir persistence (Novarino et al. 2005, Traeholt \& Mohamed 2009, Mohamed \& Traeholt 2011). In the remnant tapir populations in Thailand that are almost entirely restricted to protected areas, assessment of genetic diversity has become one of the top priorities and plays an important role in conservation management and captive breeding programs for small tapir populations. This study provides an important update on the genetic status of the Asian tapir based on mitochondrial cytochrome $b$ gene sequences. Most significantly, our study provides a set of markers to which other captive specimens may be compared in order to determine their geographic origin. This is important given that Asian tapirs are listed in CITES Appendix I, so that any captive individuals with haplotypes of an origin outside of Thailand may have been derived from questionable sources. Ex situ conservation management needs integrated information from ecological, demographic, and genetic perspectives in order to make effective decisions for captive breeding management. Data from other faster-evolving polymorphic markers such as the D-loop, the Y chromosome, and microsatellites are also needed to provide a complete picture of genetic variability of the Asian tapir from both paternal and maternal lineages. Therefore, further sampling from a broader geographic area, as well as phylogenetic analyses based on genes with more variable sites will clarify the question of genetic variation and population structure in this species. The combined data can then be used to form recommendations to ensure effective management of the species.

Acknowledgments. We acknowledge the National Research Council of Thailand and the Royal Thai Government for approval of and funding support for this project. Special thanks to the Zoological Park Organization of Thailand and the Graduate School, Department of Pathology, Faculty of Veterinary Medicine in Kasetsart University, for samples and research funding. We also thank W. Klinsawat for data arrangement. O. Oni provided useful comments on the original manuscript.

\section{LITERATURE CITED}

Arnason U, Adegoke JA, Gullberg A, Harley EH, Janke A, Kullberg M (2008) Mitogenomic relationships of placental mammals and molecular estimates of their divergences. Gene 421:37-51

Ashley M, Norman JE, Stross L (1996) Phylogenetic analysis of the perissodactylan family Tapiridae using mitochondrial cytochrome $c$ oxidase (COII) sequences. J Mamm Evol 3:315-326

Bandelt HJ, Forster P, Röhl A (1999) Median-joining networks for inferring intraspecific phylogenies. Mol Biol Evol 16:37-48

Carter DC (1984) Perissodactyls. In: Anderson S, Jones JJK (eds) Orders and families of recent mammals of the world. John Wiley \& Sons, New York, NY, p 549-562

Corbet GB, Hill JE (1992) The mammals of the Indomalayan region. Oxford University Press, New York, NY

> De Bruyn M, Nugroho E, Hossain MM, Wilson JC, Mather PB (2005) Phylogeographic evidence for the existence of an ancient biogeographic barrier: the Isthmus of Kra Seaway. Heredity 94:370-378

$>$ De Thoisy B, Da Silva AG, Ruiz-García M, Tapia A and others (2010) Population history, phylogeography, and conservation genetics of the last Neotropical mega-herbivore, the lowland tapir (Tapirus terrestris). BMC Evol Biol 10:278

Desmarest AG (1819) Nouveau dictionnaire d'histoire naturelle. Chez Deterville, Paris

Felsenstein J (1985) Confidence limits on phylogenies: an approach using the bootstrap. Evolution 39:783-791

Frankham R (1995) Effective population size/adult population size ratios in wildlife: a review. Genet Res 66:95-107

Frankham R, Ballou JD, Briscoe DA (2002) Introduction to conservation genetics. Cambridge University Press, Cambridge

Hughes JB, Round PD, Woodruff DS (2003) The Indochinese-Sundaic faunal transition at the Isthmus of Kra: an analysis of resident forest bird species distributions. J Biogeogr 30:569-580

Hulbert R (1995) The giant tapir Tapirus haysii, from Leisey Shell Pit 1a and other Florida Irvingtonian localities. Bull Fla Mus Nat Hist 37(Pt II):515-551

> Inger RF, Voris HK (2008) The biogeographical relations of the frogs and snakes of Sundaland. J Biogeogr 28: 863-891

Keller LF, Waller DM (2002) Inbreeding effects in wild populations. Trends Ecol Evol 17:230-241

Liao PC, Chiang YC, Huang S, Wang JC (2009) Gene flow of Ceriops tagal (Rhizophoraceae) across the Kra Isthmus in Thai Malay Peninsula. Bot Stud 50:193-204

Lynam AJ, Traeholt C, Martyr D, Holden J, Kawanishi K, van Strien NJ, Novarino W (2008) Tapirus indicus. IUCN Red List of Threatened Species: Version 2012.2. www. iucnredlist.org (accessed on 4 February 2013)

> Lynam AJ, Tantipisanuh N, Chutipong W, Ngoprasert D and others (2012) Comparative sensitivity to environmental variation and human disturbance of Asian tapirs (Tapirus indicus) and other wild ungulates in Thailand. Integr Zool 7:389-399

- Meijaard E (2003) Mammals of South-east Asian islands and their Late Pleistocene environments. J Biogeogr 30: 1245-1257

Mohamed NZ, Traeholt C (2011) A preliminary study of habitat selection by Malayan tapir, Tapirus indicus, in Krau Wildlife Reserve, Malaysia. Tapir Conserv 19:32-33 
Murphy WJ, Eizirik E, Johnson WE, Zhang YP, Ryder OA, O'Brien SJ (2001) Molecular phylogenetics and the origins of placental mammals. Nature 409:614-618

Nei M, Kumar S (2000) Molecular evolution and phylogenetics. Oxford University Press, New York, NY

Norman JE, Ashley MV (2000) Phylogenetics of Perissodactyla and tests of the molecular clock. J Mol Evol 50: $11-21$

Novarino W, Kamilah SN, Nugroho A, Janra MN, Silmi M, Syafri M (2005) Habitat use and density of the Malayan tapir (Tapirus indicus) in the Taratak Forest Reserve, Sumatra, Indonesia. Tapir Conserv 14:28-30

O'Brien SJ (1994) A role for molecular genetics in biological conservation. Proc Natl Acad Sci USA 91:5748-5755

> O'Leary MA, Gatesy J (2008) Impact of increased character sampling on the phylogeny of Cetartiodactyla (Mammalia): combined analysis including fossils. Cladistics 24 : 397-442

Ogata M, Watanabe S, Ogawa H (2009) Genetic variation of Asian tapir. Jpn J Wildl Med 14:73-76

Padilla M, Dowler R (1994) Tapirus terrestris. Mamm Species 481:1-8

Pitra C, Veits J (2000) Use of mitochondrial DNA sequences to test the Ceratomorpha (Perissodaactyla: Mammalia) hypothesis. J Zool Syst Evol Res 38:65-72

Rovie-Ryan JJ, Traeholt C, Marilyn-Jaoi E, Zainuddin ZZ and others (2008) Sequence variation in Malayan tapir (Tapirus indicus) inferred using partial sequences of the cytochrome $b$ segment of the mitochondrial DNA. J Wildl Parks 25:16-18

Saitou N, Nei N (1987) The neighbor-joining method: a new method for reconstructing phylogenetic trees. Mol Biol Evol 4:406-425

Sanches A, Perez WAM, Figueiredo MG, Rossini BC, Cervini M, Galetti PM Jr, Galetti M (2011) Wildlife forensic DNA and lowland tapir (Tapirus terrestris) poaching. Conserv Genet Resour 3:189-193

Schoch RM (1989) A review of the tapiroids. In: Prothero DR,

Editorial responsibility: Al Glen,

Lincoln, New Zealand
Schoch RM (eds) The evolution of perissodactyls. Oxford University Press, New York, NY, p 299-320

Slate J, Kruuk LEB, Marshall TC, Pemberton JM, CluttonBrock TH (2000) Inbreeding depression influences lifetime breeding success in a wild population of red deer (Cervus elaphus). Proc R Soc Lond B Biol Sci 267: 1657-1662

Springer MS (1997) Molecular clocks and the timing of the placental and marsupial radiations in relation to the Cretaceous-Tertiary boundary. J Mamm Evol 4:285-302

Steiner CC, Ryder OA (2011) Molecular phylogeny and evolution of the Perissodactyla. Zool J Linn Soc 163: 1289-1303

Tamura K, Peterson D, Peterson N, Stecher G, Nei M, Kumar S (2011) MEGA5: molecular evolutionary genetics analysis using maximum likelihood, evolutionary distance, and maximum parsimony methods. Mol Biol Evol 28: 2731-2739

Thompson JD, Higgins DG, Gibson TJ (1994) CLUSTAL W: improving the sensitivity of progressive multiple sequence alignment through sequence weighting, position-specific gap penalties and weight matrix choice. Nucleic Acids Res 22:4673-4680

Tonni EP (1992) Tapirus Brisson, 1762 (Mammalia, Perissodactyla) en el Lujanense (Pleistoceno Superior-Holoceno Inferior) de la Provincia de Entre Rios, Republica Argentina. Ameghiniana 29:3-8

> Tougard C, Delefosse T, Hanni C, Montgelard C (2001) Phylogenetic relationships of the five extant rhinoceros species (Rhinocerotidae, Perissodactyla) based on mitochondrial cytochrome $b$ and 12S rRNA genes. Mol Phylogenet Evol 19:34-44

Traeholt C, Mohamed MS (2009) Population estimates of Malay tapir, Tapirus indicus, by camera trapping in Krau Wildlife Reserve, Malaysia. Tapir Conserv 18:12-20

> Woodruff DS (2003) Neogene marine transgressions, palaeogeography and biogeographic transitions on the Thai-Malay Peninsula. J Biogeogr 30:551-567

Submitted: November 21, 2012; Accepted: March 18, 2013 Proofs received from author(s): June 20, 2013 